\title{
Significance of Genus-Level Taxonomic Composition of Alpine Leaf Beetles (Coleoptera, Chrysomelidae) for Zoogeographic Studies $^{\dagger}$
}

Yuri Mikhailov 1,*

Citation: Mikhailov, Y. Significance of genus-level taxonomic composition of alpine leaf beetles (Coleoptera, Chrysomelidae) for zoogeographic studies, in Proceedings of the 1st International Electronic Conference on Entomology, 1-15 July 2021, MDPI: Basel, Switzerland, doi:10.3390/IECE-10388

Published: 30 June 2021

Publisher's Note: MDPI stays neutral with regard to jurisdictional claims in published maps and institutional affiliations.

Copyright: (c) 2021 by the authors. Submitted for possible open access publication under the terms and conditions of the Creative Commons Attribution (CC BY) license (http://creativecommons.org/licenses /by/4.0/).
1 Dept. of Ecology \& Nature Management, Ural State Forest Engineering University, Sibirsky trakt, 37-620100 Yekaterinburg, Russia; yuemikhailov@gmail.com

* Correspondence: yuemikhailov@gmail.com

† Presented at the 1st International Electronic Conference on Entomology (IECE 2021), 1-15 July 2021; Available online: https://iece.sciforum.net/.

\begin{abstract}
Composition of subfamilies in leaf beetles can be used for faunistic comparisons of large zoogeographic units. In the Arctic and alpine regions of Palaearctic subfamily Chrysomelinae is dominating and composition of its genera (subgenera) is very peculiar. Several genera are typically and exclusively alpine, others include alpine species in exact subgenera. The most speciose genus Oreomela Jcbs. (over 80 species) is distributed throughout the high mountains of Central Asia, with the centre of diversity in Tien-Shan and its northern limit in the mountains of South Siberia. Genus Xenomela Weise (11 species) is restricted to Tien-Shan, Parambrostoma Chen (7 species) is distributied in the southern slope of the Himalayas. Genus Oreothassa Jcbs. with two species and monotypic Apterocuris Jcbs. are endemic to Altai Mts. Genus Suinzona Chen (20 species) is distributed mainly in the Hengduan Mountain region of China. Sclerophaedon Weise demonstrates unique situation with three centers of diversity, in Europe, China (Sichuan, Gansu) and Nepal. True alpine communities in Europe host the diverse genus Oreina Chevr. (24 species). Outside European mountains two alpine species of Oreina are represented Altai-Sayan Mountains. In alpine zone of the Urals represented by alpine tundra communities Oreina is absent but Chrysolina demonstrates peculiar composition of subgenera: Pleurosticha + Arctolina + Pezocrosita + Crositops. Both Pleurosticha and Arctolina are typical arctic-alpine subgenera of Northern Asia. West Sayan hosts endemic subgenus Paraheliostola L.Medv. and composition of Chrysolina subgenera there is Pleurosticha + Paraheliostola + Chrysocrosita. Chrysocrosita is common for the Sayans with Mongolian Altai and the Far Eastern mountains. Therefore genus-level taxonomic composition of alpine leaf beetles reveals both distinguishing features of exact mountain systems and their interconnections.
\end{abstract}

Keywords: alpine communities; leaf beetles; taxonomic composition; mountains of Eurasia

Since Lev Medvedev [1] demonstrated that composition of the subfamilies in leaf beetles (Chrysomelidae) can be used for faunal comparisons of the zoogeographic units of different scales this approach keeps its value but is quite rarely in use. My 25-years' experience of examination of alpine insect communities and alpine species of leaf beetles partly in the frame of international mountain biodiversity networks ALPNET, GMBA and GLORIA enables me to present a review of taxonomic composition worthy usage. In the Arctic and alpine regions of Eurasia only one subfamily Chrysomelinae is dominating and composition of its genera is especially peculiar. In the megadiverse genus Chrysolina Motschulsky only exact subgenera include alpine species therefore composition of such subgenera is important. Several genera are typically and exclusively alpine, among them the most speciose is Oreomela Jacobson with over 80 species distributed 
throughout the high mountains of Central Asia with the center of diversity in Tien-Shan and its northern limit in the mountains of South Siberia [2]. Genus Xenomela Weise (11 species) is restricted to Tien-Shan, Parambrostoma Chen (7 species) is distributed in the southern slope of the Himalayas [3] and Suinzona Chen (20 species) - mainly in the Hengduan Mountain region of China [4]. Genus Oreothassa Jacobson with two species and monotypic Apterocuris Jacobson are endemic to Altai Mountains. Sclerophaedon Weise demonstrates [5] three isolated centers of diversity, in Europe, Nepal and Sichuan and Gansu provinces of China. The historic ties between these centers are intriguing but still have not investigated.

Vegetation types of alpine zone influence the composition of herbivores as well. The true alpine communities of European mountains host 24 species of Oreina Chevr. This genus is absent in the Caucasus and only two species are known from Altai-Sayan Mountains, where true alpine communities are less common than alpine tundra. In the Urals and all Siberian mountains alpine tundra communities predominate in the highest parts. In the Urals Chrysolina demonstrates peculiar composition of subgenera: Pleurosticha + Arctolina + Pezocrosita or Crositops. Both Pleurosticha and Arctolina are typical arctic-alpine subgenera of Northern Asia and they are known throughout the whole range of the Urals, from its highest peaks in the South up to the North Polar Circle. Pezocrosita from North Urals and Crositops from South Urals, both found by me only recently [6], show historical connections between these parts of the Urals with West Altai and West Sayan respectively (Fig. 1). West Altai is peculiar with the endemic subgenus Sibiriella L. Medvedev and the composition of Chrysolina subgenera there is Sibiriella + Pleurosticha + Pezocrosita West Sayan hosts the endemic subgenus Paraheliostola L. Medvedev and the composition of Chrysolina subgenera there is Pleurosticha + Paraheliostola + Chrysocrosita . Chrysocrosita is common for the Sayans with Mongolian Altai and the mountains of the Pacific coast of Eurasia (Fig. 1).

Clearly the taxonomic composition of leaf beetles from the highest mountains such as Himalaya, Tibet, Yunnan is especially interesting for understanding the evolutionary interconnections of Asian alpine biota. But the specific problem arises for Chrysolina, where the system of generally recognized subgenera cannot be applied exactly for these extremely high mountain species as illustrated in Nepal Himalaya [7]. In this case the provisional "species groups" can be used instead of subgenera for Chrysolina. The further problem is to find relations of these "species groups" to generally recognized subgenera; it can be solved only by means of molecular phylogenetic studies.

The presented review of known cases of genus-level taxonomic composition of alpine leaf beetles reveals both distinguishing features of exact mountain systems and their interconnections. Our knowledge of alpine leaf beetles as well as other Coleoptera families in high mountains is incomplete and a lot of undescribed species are still waiting for their collectors. The obtained data shows possible scenarios of historical formation of alpine biota that gives a general overview only and could be verified by both molecular approaches and fossil findings. 




Figure 1. Several examples of the composition of Chrysolina subgenera tracking the interconnections between the greater mountains of Asia.

Funding: This research received no external funding.

\section{References}

1. Medvedev, L.N. Ob ispol'zovanii kolichestevennogo metoda v zoogeographii [On the use of quantitative method in zoogeography]. Uspekhi Sovr. Biol. 1993, 113, 731-739.

2. Mikhailov, Y.E. On the Northernmost Distribution of Leaf Beetles of the Genus Oreomela (Coleoptera, Chrysomelidae): New Species from Mountains of Southern Siberia. Ent. Review. 2007, 87, 740-749. DOI: 10.1134/S0013873806090053.

3. Ge, S.-Q.; Daccordi, M.; Beutel, R.G.; Ren, J.; Cui, J-Z.; Li, W.-Z. \& Yang X.-K. Revision of the Eastern Asian genera Ambrostoma Motschulsky and Parambrostoma Chen (Coleoptera: Chrysomelidae: Chrysomelinae). Syst. Entomol. 2012, 37, 332-345. DOI: 10.1111/j.1365-3113.2012.00618.x.

4. Ge, S.-Q.; Daccordi, M.; Beutel, R.G.; Li, W.-Z. \& Yang X.-K. Revision of the chrysomeline genera Potaninia, Suinzona and Taipinus (Coleoptera) from eastern Asia, with a biogeographic scenario for the Hengduan mountain region in south-western China. Syst. Entomol. 2011, 36, 644-671. DOI: 10.1111/j.1365-3113.2011.00581.x.

5. Ge, S.-Q.; Daccordi, M.; Cui, J-Z.; Ren, J. \& Yang, X.-K. Revision of genus Sclerophaedon Weise from China (Coleoptera, Chrysomelidae, Chrysomelinae). Annali Mus. Civ. Storia Natur." G. Doria". 2013, 105, 81-102.

6. Mikhailov, Y.E. On Two Little Known Species of Leaf Beetles (Coleoptera, Chrysomelidae) from the South Urals. Ent. Review. 2018, 98, 467-479. DOI: 10.1134/S0013873818040073

7. Mikhailov, Y.E. Review of the genus Chrysolina Motschulsky, 1860 (Coleoptera: Chrysomelidae) from Nepal Himalaya with description of a new species. Rus. Ent. J. 2019, 28, 58-63. DOI: 10.15298/rusentj.28.1.08 